\title{
Literatura e Cultura Popular no Cristianismo Primitivo A crença e prática do mau-olhado em Gálatas 3, 1-5
}

Orientador: Isidoro Mazzarolo

Mestrando: Daniel Brasil Justi

Área de Concentração: Teologia Bíblica

Linha de Pesquisa: Análise e Interpretação de Textos do Antigo e Novo Testamento

O trabalho tem por objetivo analisar, a partir da literatura, cultura e práticas mágicas no Mundo Antigo, a inserção das comunidades cristãs nesse ambiente vital, no geral e, da comunidade de Gálatas, no particular. O objetivo é, através da transdisciplinaridade (teologia, história, antropologia e arqueologia) reconstruir o contexto mágico originário da comunidade gálata, entender as tensões em seu interior e perceber que implicações existem em vincular essa comunidade com o ambiente da magia. O elemento mágico observado é a crença e prática do mau-olhado (baskaíno) que, por conta de processos históricos, como o Iluminismo Europeu, foi obscurecido nas modernas traduções bíblicas e comentários exegéticos. Desvelar, pois, esse "filtro de leitura" construído pela Modernidade, consiste em redimensionar as frágeis fronteiras entre magia (primitivo) e religião (civilizado), de acordo com a leitura racionalista do século XIX em diante.

Palavras-chave: Magia; Cristianismo Primitivo; Novo Testamento. 